\title{
PHYSIOTHERAPY SERVICE WITHOUT STANDARDIZED OPERATING PROCEDURES FROM PHYSIOTHERAPIST'S PERSPECTIVE: A CASE STUDY
}

\author{
Pelayanan Fisioterapi Tanpa Prosedur Operasional Standar dari Perspektif \\ Fisioterapis: Sebuah Studi Kasus
}

\author{
*Triana Karnadipa ${ }^{1}$ \\ ${ }^{1}$ Physiotherapy Department, Vocational Education Program of University of Indonesia, Jakarta, Indonesia \\ Correspondence*: \\ Address: A Building 5th Floor, Kampus UI-Depok, Indonesia | e-mail: trianakarnadipa@gmail.com
}

\begin{abstract}
Background: Treatment variations have been considered as a sign of an inappropriate healthcare service whether due to the underuse or the overuse of resources. To reduce these variations, establishing and implementing well-developed standardized operating procedures (SOPs) and evidence-based standardized clinical guidelines is required. A rehabilitation unit for children with disabilities in Makassar did not implement any SOPs or standardized clinical guidelines in their service and treatment. This conduct may have an adverse effect on physiotherapists' professionalism.

Aims: The study aimed to explore the possible impact of community-based rehabilitation (CBR) practice with no SOPs and evidence-based standardized clinical guidelines on the physiotherapists.

Method: This study was a qualitative case study. The CBR unit was observed for 278-hours and the study conducted three semistructured interviews. Three physiotherapists voluntarily participated in the study. Open, axial, and selective coding were conducted to encode the interview findings. The findings from observation encoded interview, field, and self-reflective notes were triangulated, analyzed thematically, and illustrated by the explorative model.

Results: Working with no SOPs and guidelines was associated with variations in procedures by physiotherapists, irregularity in their treatment choices, liability feeling toward errors making, and Low self-confidence in their professionalism.

Conclusion: Working without SOPs and guidelines was associated with psychological exertion of the physiotherapists. They showed uncertainty in their professional capabilities as a physiotherapist. It is recommended for YPAC Makassar city to develop SOPs and evidence-based standardized clinical guidelines for their organization.
\end{abstract}

Keywords: children, community-based rehabilitation, disability, guidelines, standard-operating procedure

\begin{abstract}
Abstrak
Latar Belakang: Variasi pengobatan telah dipertimbangkan sebagai salah satu tanda pelayanan kesehatan yang tidak layak. Salah satu cara untuk mengurangi variasi tersebut adalah dengan menyusun dan mengimplementasikan sebuah prosedur operasional standar (SOP) dan panduan standar klinis berbasis evidens. Sebuah unit rehabilitasi berbasis komunitas (CBR) untuk anak-anak dengan disabilitas di kota Makassar tidak mengimplementasikan SOP dan panduan standar klinis berbasis evidens dalam memberikan pelayanan dan pengobatan pada klien mereka.

Tujuan: Tujuan dari studi kasus ini adalah untuk mengetahui dampak yang mungkin terjadi pada sebuah praktik rehabilitasi berbasis komunitas tanpa SOP dan panduan standar klinis pada fisioterapis.

Metode: Studi ini adalah studi kasus kualitatif. Unit CBR diobservasi selama 278 jam dan melakukan tiga wawancara semi terstruktur. Tiga orang fisioterapis bersedia menjadi partisipan studi ini. Teknik pengkodean terbuka, aksial, dan selektif digunakan untuk mengkodekan hasil temuan wawancara. Temuan dari observasi, interview yang di-coding, catatan lapangan, dan refleksi diri ditriangulasikan dan dianalisis secara tematik. Model eksploratif yang mengilustrasikan empat temuan kunci dibuat. Hasil: Fisioterapis secara umum mengkhawatirkan prosedur dan penanganan yang bervariasi, ketidaktentuan dalam pemillihan terapi, rasa bersalah ketika membuat kesalahan, dan kurang rasa percaya diri sendiri terhadap profesionalisme mereka. Kesimpulan: Bekerja tanpa SOP menyebabkan beban psikologis bagi fisioterapis. Mereka mengekspresikan kecemasan dengan mempertanyakan kapabilitas profesional mereka sebagai fisioterapis. YPAC Makassar direkomendasikan untuk mengembangkan secara khusus sebuah SOP dan panduan standar klinis sesuai tujuan organisasi mereka.
\end{abstract}

Kata kunci: anak, disabilitas, panduan, prosedur operasional standar, rehabilitasi berbasis komunitas 


\section{Introduction}

Disable people in developing countries live in stigmatization and poverty and have limited access to rehabilitation services (Achu et al.,2010). Therefore, World Health Organization established community-based rehabilitation (CBR) which is an approach to facilitate healthcare and rehabilitation for disabled people in developing countries (World Health Organization, 2010). More than 90 countries in the world are developing their CBR units which are mostly organized by non-profit organizations targeting the poor disabled individuals.

CBR units in Indonesia have been operating for 28 years, mainly in Java, Sumatra, and Sulawesi Island (Comcec Coordination Office, 2016). Disabled Children Development Foundation or Yayasan Pembinaan Anak Cacat (YPAC) is the oldest CBR unit for disabled children in Indonesia. Now, YPAC has 16 branches throughout Indonesia, including Makassar city. The mission of YPAC is to support Indonesian children with physical disabilities (Jonathan, 2002). The aids and services include mobility aid devices, rehabilitation, and consultation; however, rehabilitation is not provided anymore by the ongoing national CBR units. Therefore, YPAC is considered the primary support for low-income families of disabled children in Indonesia (Primadi and Budijanto, 2014).

A previous study showed that the recent unit does not rely on standardized operating procedures (SOPs) or evidencebased standardized clinical guidelines (Karnadipa and Nurfikri, 2020). This condition created wide variations in rehabilitative treatment and practice (Naylor et al., 2019). As a consequence, the patient may not receive the most appropriate treatment along with the limited resources. Chaves et al. (2020) presented that this situation may reduce income and healthcare services efficiency. However, based on our literature review, no previous study evaluated the impact of variations on the Indonesian CBR units, especially for physiotherapists.

Minimizing inappropriate variations, especially in treatment choices, is one of the prudent healthcare principles.
Variations have been considered an indication of improper healthcare services associated with underuse or overuse of resources (Woolf et al., 1999). To reduce the variations, the development and implementation of evidence-based guidelines are needed for higher clinical outcomes and more consistent healthcare services (Woolf et al., 1999; Fakhry et al., 2004; Arabi et al., 2010; Shafi et al., 2014).

Based on this background, this study aimed to analyze the impact of variations in a CBR unit with no standardized operating procedures or evidence-based standardized clinical guidelines on the physiotherapists. Thus, the study would target a CBR unit to show the influence of practicing without standardized operating procedures or clinical guidelines on their healthcare workers.

\section{Method}

This study was a qualitative case study conducted from May to October 2019. Data were collected through observation and semi-structured interviews. This study was conducted at the CBR unit at the physiotherapy department in YPAC Makassar city. A research permit was obtained from the head of the department to evaluate the healthcare delivery. The researcher was a female physiotherapist with four years of experience. She volunteered to be a physiotherapist in this unit from 2015 to 2016. She spent most of her life in Makassar city in Indonesia.

The study used purposive sampling. The inclusion criteria included having one year of experience at YPAC Makassar city and approving for the informed consent. Three female physiotherapists voluntarily agreed to participate. The ranged age of participants was 25 to 29 years with an average of 27 years old. All of the participants had national licenses and two years of experience at YPAC Makassar city. The informed consent contained the research objectives, protocols, benefits, potential risks, and ethical tenets. All therapists' inquiries were answered before the consent agreement.

The unit was observed intensively for 278 hours ( 6 to 7 hours in a day for 40 days) 
from May to July 2019. The observations were recorded. The researcher participated as a physiotherapist and wrote selfreflective notes to minimize any possible observer bias. The observation procedure included the services and interaction process between physiotherapists, children, and parents. Moreover, the errors contributing factors to rehabilitative service were observed, analyzed, and categorized. A fishbone chart was used to illustrate the relationship between the contributing factors. The findings were synthesized in a systematic and structured approach (Cleland, Habli and Medhurst,2012). However, the article only discussed the procedural factors related to SOPs and clinical guidelines.

Three semi-structured interviews were conducted from September to October 2019 for 60 minutes. The participants were interviewed to get all possible information. The respondents' identities were anonymized for confidentiality purposes. The interviews were conducted using Bahasa Indonesia and audiotaped with a tape recorder. Their facial expression and behaviors during the interview were directly documented after the interview. Then, the interviews were recorded, transcripted verbatim, and inductively analyzed (Streubert and Carpzenter,2011).

The interviews transcriptions were coded through a series of open coding, axial coding, and selective coding. In open coding, the transcriptions were scanned line-by-line and coded by category. In axial coding, the transcriptions were coded and subcategorized regarding SOPs and clinical guidelines, then thematically arranged, compared, and inductively analyzed. Next, an explorative model was synthesized. After that, the transcriptions were translated into English and proofread by an English Translator. Finally, in selective coding, the final preposition was synthesized after rationalized the findings from both observation and structured interviews. To minimize the bias due to the researcher's assumptions, self-reflective notes were evaluated and findings were sent to the participants to get their confirmation and feedback.
The findings were analyzed and discussed. Practical recommendations were created at the three levels of the external analysis.

\section{Results and Discussion}

The results showed that the physiotherapy CBR unit received clients from Monday to Saturday from 9:00 Am to 12:00 Pm. The unit room size was $16 \times 24 \mathrm{~m}$ located at YPAC Makassar city. The unit equipment consists of four mattresses, two standing frames, a three-millimeter parallel bar, a stair set, a wall bar, a leg exercise table, two half-circle-shaped cushions, and four U-shaped cushions. It also contained sets of arm, leg, ankle, and thoracic orthosis, some were donated by previous clients. The equipment was sufficient to cover the demand of the children including children more than eight years old during the rehabilitative interventions. However, the equipment was not enough to treat more than three children in one session.

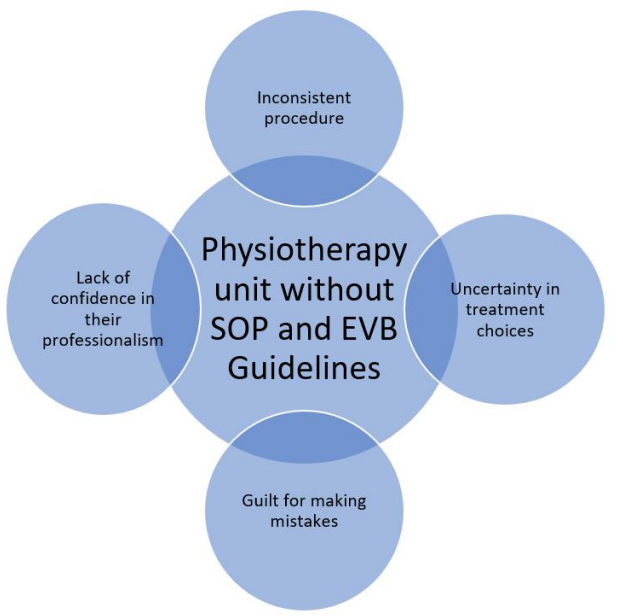

Figure 1. An explorative model illustrated consequences experienced by the physiotherapists working without SOPs and standardised clinical guidelines

The unit was officially operated by three physiotherapists on daily basis. Their expertise ranged from two years to more than ten years in pediatric rehabilitation service. Students from two local physiotherapy and nursing schools were assigned to the unit for internships of supervised practice in a certain period with a shift of one to three months. Their main tasks were to assist the therapists in providing essential therapy and healthcare for children. The unit showed neither 
standardized operating procedures (SOPs) nor evidence-based standardized clinical guidelines. The junior physiotherapists provided treatment according to their senior therapists' instruction, and their previous training, experience and academic knowledge. Most visitors were from the South Sulawesi Province and other Eastern Indonesia provinces, according to their parents' origin. The unit targeted children and young people with physical disabilities or developmental delays. The most common clinical case was cerebral palsy.

The unit has unscheduled appointments associated with an inconsistent number of clients per week. On some days, the number was high treating seven children at the same time, while on other days, it was low treating three children in the whole day. The senior physiotherapists guided the junior physiotherapists and students during the interventions. The treatment was based on academic knowledge showing no application of daily guidelines or SOPs.

The rehabilitation service may show significant errors at all healthcare system levels especially the last level (Vincent,2008). The human factors significantly have adverse effects. Thus, a fishbone chart was conducted to define and analyze these factors (Cleland, Habli, and Medhurst, 2012). The chart identified some factors including fatal ones (Figure 1).

All participants were female physiotherapists. The range of age was 25 to 29 years with an average age of 27 years old. They were nationally licensed as physiotherapists and had two years of working experience at YPAC Makassar city.

The explorative model shows the consequences of working without SOPs or guidelines in the CBR unit (Figure 2). These consequences include inconsistent procedures, uncertain treatment choices, high mistakes liability, and low selfconfidence of physiotherapists. The lack of tracking standardized pathways was associated with service delivery variations. Thus, the risk of service delivery errors increased causing confusion and insecurity feelings within the physiotherapists.

\section{Variations in procedures and treatment}

The variations mainly occurred in the physiotherapy management and administration department. The administration process and payment were not admitted to the parents in the first visit with no further clarification from the parents. However, some administration process was applied on the second visit using paper forms.

The administration process could be postponed in the absence of the charge senior physiotherapist. The process involved scheduling the visits and establishing payments using a computer database for electronic data.

Therapist A said, "When a new patient comes, a therapist who is in charge does not discuss the administration process and payment."-P3

"The therapist (who is in charge of administration) is sometimes not available" - P4

"The parents do not usually ask about the payment. They mostly know after a few visits." $-P 5$

The physiotherapists did not know the exact delivery information to parents, besides the absence of any regulating SOPs or communication guidelines in the unit. Thus, the parents received variant information from the physiotherapists. However, the parents' characteristics may play a prominent role in that diversity.

Therapist C said, "We need to be smart on dealing with a particular situation. We need to choose carefully the appropriate words during communicating with the parents."-P12

"Additionally, we need to pay more attention to the parents since most of parents are sensitive."-P13

"Overall, the primary problem is the complications due to the lack of standardized operational procedures."-P14 


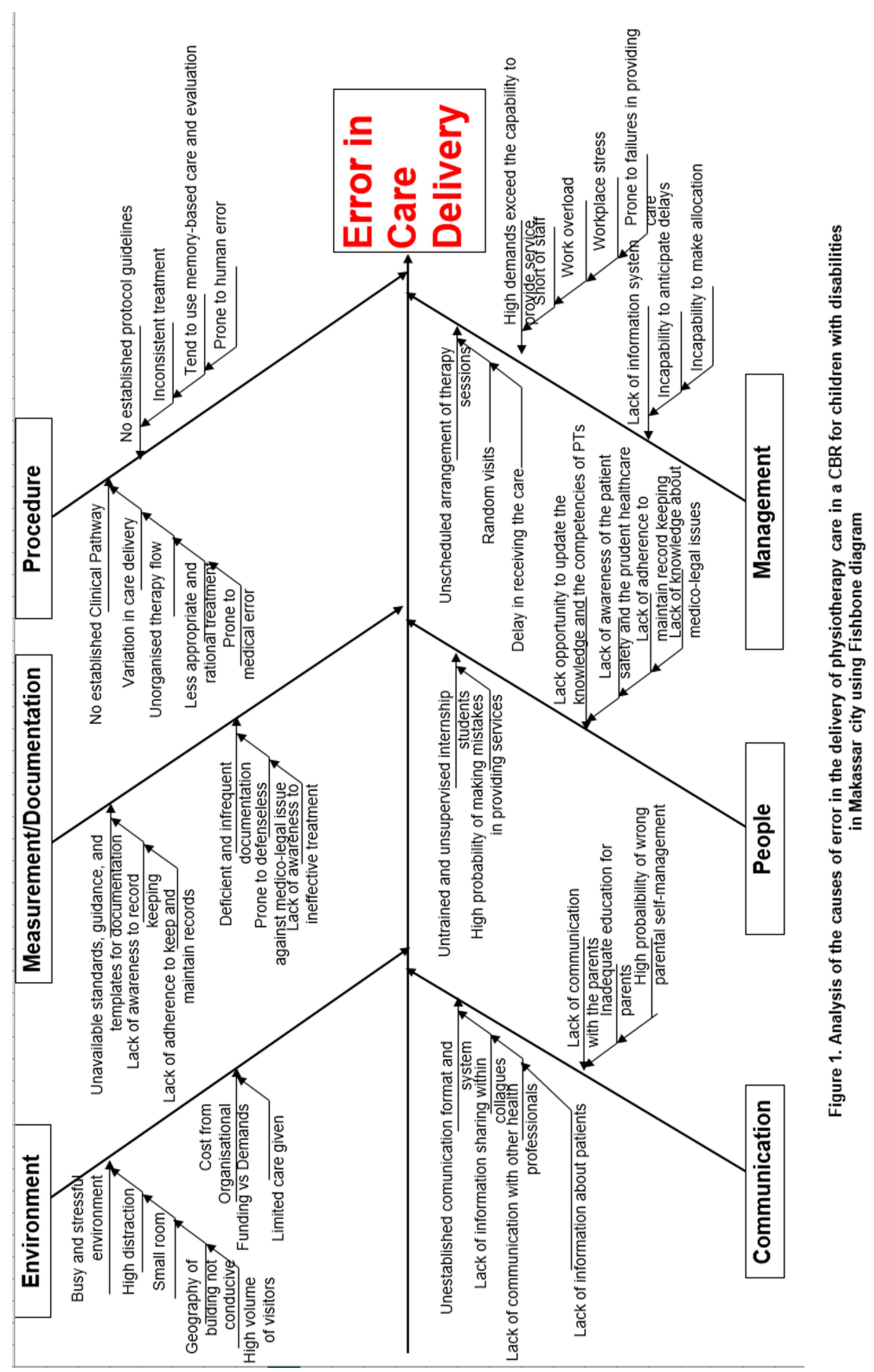


The absence of both SOPs and standardized clinical guidelines was associated with non-consistent information and unclear administration processes which complicated both decision-making and information delivery by physiotherapists to the parents.

The absence of standardized operating procedures or clinical guidelines increased mistakes risk. Similarly, Jones et al. (2016) showed that education, financial issues, human resources, and the absence of standardized clinical pathways were the leading causes of errors. Furthermore, Irgens, Henriksen and Moe (2020) found that the variations were caused by the variety in environmental contexts, patients' current functional capabilities and therapists' treatment approaches.

Similarly, another study showed that inadequate equipment and facilities; and unclear therapy plans compromised the treatment decisions (Irgens, Henriksen and Moe,2020). Moreover, therapists' approaches may vary based on their priority whether the patient's recovery or their personal goals. Therefore, the clinical guidelines should contain a standardized time and sequenced actions to achieve the objectives efficiently (Panella, Marchisio and Di Stanislao, 2003; O'Shea et al., 2006).

\section{Irregularity in physiotherapists' treatment choices}

The absence of evidence-based guidelines was linked with the lack of physiotherapists' self-confidence to make correct treatment decisions. The junior physiotherapists did not receive any standardized clinical guidelines during their first day of work. They had to observe and learn from other senior physiotherapists during their work period.

Therapist C said, "I was confused
when I started working here; there
is no guidance about treating
pediatric patients."-P10
"We needed time to learn from our
seniors who have more
experience."-P15

Therapist C said, "I was confused when I started working here; there is no guidance about treating pediatric patients." $-P 10$ We needed time to learn from our experience."-P15
However, even after the training, the physiotherapists presented uncertainty in the correctness and standardization of their interventions. They also showed their interest and support in following SOPs or guidelines in their work.

Therapist B said, "Because there are no SOPs, our interventions for patients were not clear. We keep treating the patient, but we do not know whether the intervention toward the guidelines or away from it." $-P 9$

"Could you imagine a health practitioner working efficiently with no standardized operating procedures or standardized guidelines?"-P8

The guidelines were from senior physiotherapists. Thus, the junior physiotherapists learned by observing, practicing, and discussing the treatment choices with their senior physiotherapists. The absence of SOPs and evidence-based clinical guidelines was associated with less confidence in the efficiency of their treatment choices which varied from time to time. Moreover, this may be caused by the limited number of equipment and thus the limited number of children treated simultaneously. Thus, the children had to take a turn to use one piece of equipment. A therapist would use any available tools to treat the child while waiting for their turn, not following the usual sequences. However, due to the lack of proper documentation, it is difficult to determine the leading cause for the variations

Similarly, Tracy et al. (2010) presented that healthcare systems without a standardized clinical guideline showed variant interventions and more clinical symptoms and thus more difficulty in the evaluation (Tracy et al., 2010). Furthermore, evaluating the current treatment whether it is overtreating or undertreating is not easy due to lack of proper documentation and audit.

The clinical decision should rely on evidence and be supported by transparent updated documentation to be consistent, reliable, effective, and measurable (Varkey, Reller and Resar, 2007; Zhang and 
Liu,2011). As a consequence, improper variations would be diminished. Moreover, this evidence-based approach is needed to get proper consistent treatment choices (Welsh Government,2016). Therefore, it is recommended to develop clinical evidencebased guidelines in this CBR unit.

\section{Liability for conducting errors}

The physiotherapists showed a tendency to feel afraid of making mistakes or breaking laws by working with no SOPs and evidence-based guidelines besides feeling responsible since the patients are capable children.

Therapist B said, "I have worked in YPAC for approximately two years. During my work, I did not receive any SOPs. In my opinion, a clinical work without SOPs is illegal"--P6

Therapist $C$ said, "I am afraid to make mistakes. Moreover, I have to treat a child along with his/her parents. "-P11

The physiotherapists were uncertain about their practice without evidencebased guidelines and worried about making errors. They were aware of the importance of SOPs and guidelines as legal requirements in rehabilitation services.

Furthermore, physiotherapists addressed their liability of conducting mistakes in the therapy sessions associated with the absence of evidencebased guidelines. These results are confirmed by Treiber and Jones (2018) who found that $55 \%$ of nursing graduates who did medication error experienced emotional distress afterward. However, no specific errors were detected in the study due to the absence of guidelines.

Moreover, another study supported the results by confirming that more errors occur if healthcare is based on memory rather than guidelines (Tracy et al., 2010). This phenomenon was explained further by Reason (2000) showing the limited capability of the human brain to store and process information. There is a gap between the moment of formulating intention and executing the intended action. This gap leads to failure of memorizing process within the proper place and time causing the most common forms of human errors (Reason,2000). Standardizing rehabilitation protocols and therapists' tasks is required to minimize errors. This strategy led to consistent tasks and interventions reducing the variations in rehabilitation service (Hougaard,2004; Cristian and Tran,2012).

\section{Low self-confidence of physiotherapists toward their professionalism}

The physiotherapists believed that healthcare practice with no SOPs and standardized clinical guidelines is an unprofessional matter that should be corrected.

Therapist $A$ said, "Regarding the system, sometimes I feel that it lacks professionalism"-P2

Sometimes, I feel a lack of professionalism. Sometimes I tell myself that I should not work like this."-P1 Therapist $B$ said, "SOPs is our guidelines in working."-P7

The physiotherapists expressed their negative emotions due to working with no SOPs or standardized clinical guidelines. They believed in the role of SOPs and guidelines to guide their work system. This aligns with the Indonesian Physiotherapist Ethical Code, article 10a, which dictates that "a physiotherapist must provide treatment according to a standard consisting of manual and clinical services guideline" (Ikatan Fisioterapi Indonesia,2019).

A standardized clinical pathway is required to facilitate the therapists' understanding of their roles and responsibilities, leading to better information sharing and integration in every level of the CBR system (Panella, Marchisio and Di Stanislao,2003). A systematic review by Rotter et al. (2012) found that implementing a clinical pathway in a healthcare system could reduce safety risks by $5.6 \%$. Additionally, the higher the quality of documentation, the more commitment toward guidelines.

Along with the study, Schröder et al. (2020) evaluated the impact of the 
application of a model in lower back pain units. The study found that the implementation of treatment recommendations increased the physiotherapists' self-confidence and improved their attitudes and beliefs. Their self-confidence and positive behavior lasted for three to twelve months maximally.

Schröder et al. (2020) emphasized that organizational resources and support are the main barriers in the implementation of guidelines. It is because establishing and implementing a clinical pathway involves collaboration between interdisciplinary teams and is time-consuming ( $O$ 'Shea et al., 2006). Therefore, it is recommended for the managers and physiotherapists to build relationships and communicate at the organizational level. This will facilitate guidelines access to the whole physiotherapists within the organization leading to more adherence to them.

Similarly, Higuchi et al. (2012) investigated the impact of standardized guidelines implementation on nurses and midwives in the rural community health service in Timor Leste. Along with this study, the respondents were aware of the standardized guidelines, but there was a difference in their knowledge of guidelines' content. They also expressed a lack of confidence and uncertainty during their work experience.

Higuchi et al. (2012) also found that the standardized guidelines had a positive impact on health practitioners in a developing country, especially in the rural community setting. The application of standardized guidelines by nurses and midwives increased their confidence in their practice and medical intervention. Moreover, patients became more satisfied with their practice. The standardized guidelines also facilitated the practitioners' work. Thus, it is highly recommended to implement well-developed standardized guidelines for rehabilitation services for children with disabilities in YPAC Makassar city to raise the physiotherapists' work level and self-confidence.

Evidence-based clinical practice showed that the Indonesian Physiotherapy Association and the Non-Government Organisation have not yet established quality assurance standards, recordkeeping guidance, or standardized clinical guidelines in community rehabilitation services. As a consequence, the physiotherapist may not work professionally and show less care to the children. However, insufficient adherence to clinical guidelines and the standardized procedure is considered a law-breaking matter (Pearson, 2008). This may associate with the low tendency of workers to observe, care or evaluate their practice.

\section{Limitations}

The study limitations were the small number of participants with only three participants. However, sufficient data were obtained due to the redundancy of responses. Moreover, the effect of working without SOPs and guidelines on the children could not be triangulated due to improper documentation.

\section{Recommendations}

The study recommended three levels of external analysis as follows: 1) Macro Level: Checking the current services in Indonesian CBR units; Developing guidelines to promote the referral system for CBR units; Creating an organizational reporting system to evaluate and investigate the services errors. 2) Muso Level: Setting clinical pathways for pediatric rehabilitation; Implementing evidence-based guidelines for rehabilitation of children with disabilities. 3) Micro Level: Training the therapists to enhance their skills, proficiencies, awareness, and practice; Evaluating the current practice and service delivery; Building relations and communicating at the organizational level.

\section{Conclusion}

The study highlighted the physiotherapists' experience in a unit with no SOPs and evidence-based standardized clinical guidelines. The results showed variations in physiotherapists' procedures and treatment, irregularity in their treatment 
choices, liability feeling toward conducting errors, and low self-confidence toward their professionalism. However, it is difficult to evaluate the tangible impact of the lack of SOPs and standardized clinical guidelines on children, families, and healthcare services. Improper documentation is the leading cause of evaluation inability due to the lack of data needed for analysis. This study shows the prominent need for the development of SOPs and standardized clinical guidelines in the CBR unit for children with disabilities.

This study provided an in-depth insight into SOPs and standardized clinical guidelines. It also supported their implementation process to achieve prudent healthcare, especially rehabilitative healthcare in Indonesia. Future studies including more Indonesian CBR units or healthcare services with no standardized clinical guidelines and SOPs are suggested to evaluate their impact on more complex rehabilitative services.

\section{Abbreviations}

CBR: Community-Based Rehabilitation

SOPs: Standard operation procedures

YPAC: Yayasan Pembinaan Anak Cacat

\section{Declarations}

\section{Ethics Approval and Consent Participant}

This study was permitted by manager of Yayasan Pembinaan Anak Cacat Makassar. All participants provided written informed consent prior to enrolment in the study.

\section{Conflict of Interest}

The author declares that there is no significant conflict of financial and personal interests that may affect the work performance or presentation.

\section{Availability of Data and Materials}

Data dan materials are provided on request

\section{Author Contribution}

Author contributed to the conceptualization of work, data acquisition, and analysis of data, drafting, revising, and final approval of the version to be published.

\section{Acknowledgment}

The authors would like to thank the manager of YPAC Makassar city for his permission and information and the therapists for their voluntary participation in this study

\section{References}

Achu, K. et al. (2010) Introductory booklet CBR Guidelines. Edited by $\mathrm{C}$. Khasnabis and K. H. Motsch. Geneva: World Health Organization Press.

Arabi, Y. M. et al. (2010) "Mortality reduction after implementing a clinical practice guidelines-based management protocol for severe traumatic brain injury," Journal of Critical Care, 25(2), pp. 190-195. doi: 10.1016/j.jcrc.2009.05.004.

Basaninyenzi, U. (2020) Disability Inclusion, worldbank.org. Available at:

https://www.worldbank.org/en/topic/d isability (Accessed: January 26, 2021).

Chaves, G. et al. (2020) "Cardiac rehabilitation dose around the world: Variation and correlates," Circulation: Cardiovascular Quality and Outcomes, (January), pp. 1-13. doi: 10.1161/CIRCOUTCOMES.119.005 453.

Cleland, G., Habli, I. and Medhurst, J. (2012) Using safety cases in industry and healthcare. London: Health Foundation Evidence:

Comcec Coordination Office (2016) The Role of Community-Based Rehabilitation in Poverty Reduction: A Comparative Study among Iran , Malaysia , and Indonesia The Role of Community-Based Rehabilitation in Poverty Reduction: A Comparative Study among Iran, Malaysia, and Indonesia This re. Ankara.

Cristian, A. and Tran, A. (2012) "Patient Safety in Cancer Rehabilitation," 23, pp. 441-456. doi: 10.1016/j.pmr.2012.02.015.

Fakhry, S. M. et al. (2004) "Management of Brain-Injured Patients by an Evidence-Based Medicine Protocol Improves Outcomes and Decreases 
Hospital Charges," Journal of Trauma - Injury, Infection and Critical Care, 56(3), pp. 492-500. doi: 10.1097/01.TA.0000115650.07193.6 6.

Higuchi, M. et al. (2012) "Application of standard treatment guidelines in rural community health centres, TimorLeste," Health Policy and Planning, 27(5), pp. 396-404. doi: 10.1093/heapol/czr051.

Hougaard, J. (2004) "Developing evidencebased interdisciplinary care standards and implications for improving patient safety," International Journal of Medical Informatics, 73(7), pp. 615-624. doi: https://doi.org/10.1016/j.jjmedinf.200 4.04.015.

Ikatan Fisioterapi Indonesia (2019) Kode Etik Fisioterapi Indonesia, Ikatan Fisioterapi Indonesia.

Irgens, E. L., Henriksen, N. and Moe, S. (2020) "Variations in physiotherapy practice in neurological rehabilitation trajectories -an explorative interview and observational study," Physiotherapy Theory and Practice, 36(1), pp. 95-107. doi: 10.1080/09593985.2018.1480679.

Jonathan, M. (2002) Participatory Need Assessment of CBR for People with Disabilities and Community in Indonesia. Solo: PPRBM Prof. Dr. Soeharso YPAC Pusat (CBR Development and Training Center).

Jones, C. A. et al. (2016) "Total joint arthroplasty: practice variation of physiotherapy across the continuum of care in Alberta," BMC Health Services Research, 16(1), pp. 1-7. doi: 10.1186/s12913-016-1873-9.

Karnadipa, T. and Nurfikri, A. (2020) "Physiotherapy Service Without Documentation At A Community Based Rehabilitation For Children With Disabilities In Makassar City: A Case Study Of Physiotherapist' S Perspective," Jurnal Sosial Humaniora Terapan, 2(2), pp. 93100.

Naylor, J. M. et al. (2019) "Variation in rehabilitation setting after uncomplicated total knee or hip arthroplasty: A call for evidence- based guidelines," BMC

Musculoskeletal Disorders, 20(1), pp. 1-11. doi: 10.1186/s12891-0192570-8.

O'Shea, Y. et al. (2006) Improving the patient journey: understanding integrated care pathways. Dublin: National Council for the Professional Development of Nursing and Midwifery.

Panella, M., Marchisio, S. and Di Stanislao, F. (2003) "Reducing clinical variations with clinical pathways: Do pathways work?," International Journal for Quality in Health Care, 15(6), pp. 509-521. doi: 10.1093/intqhc/mzg057.

Pearson, G. (2008) "Why Children Die: the report of a pilot confidential enquiry into child death by CEMACH (Confidential Enquiry into Maternal and Child Health)," Clinical Risk, 14(5), pp. 166-168. doi: 10.1258/cr.2008.080042.

Primadi, O. and Budijanto, D. (2014) Situasi Penyandang Disabilitas, Buletin Jendela Data \& Informasi Kesehatan. Edited by R. Aprianda and F. I. Herman. Jakarta: Pusat Data dan Informasi Kementerian Kesehatan RI. doi: 10.1007/s13398-014-01737.2 .

Reason, J. (2000) "Human error: Models and management," British Medical Journal, 320(7237), pp. 768-770. doi: 10.1136/bmj.320.7237.768.

Rehabilitation, U. N. C. et al. (2010) "CBR in Indonesia Introduction."

Rotter, T. et al. (2012) "The Effects of Clinical Pathways on Professional Practice, Patient Outcomes, Length of Stay, and Hospital Costs: Cochrane Systematic Review and Meta-Analysis," Evaluation and the Health Professions, 35(1), pp. 3-27. doi: $10.1177 / 0163278711407313$.

Schröder, K. et al. (2020) "Confidence, attitudes, beliefs and determinants of implementation behaviours among physiotherapists towards clinical management of low back pain before and after implementation of the BetterBack model of care," $B M C$ Health Services Research, 20(1), pp. 
1-15. doi: 10.1186/s12913-02005197-3.

Shafi, S. et al. (2014) "Compliance with recommended care at trauma centers: Association with patient outcomes," Journal of the American College of Surgeons, 219(2), pp. 189-198. doi: 10.1016/j.jamcollsurg.2014.04.005.

Streubert, H. J. and Carpenter, D. R. (2011) Qualitative Research in Nursing: Advancing the Humanistic Imperative. Fifth. Philadelphia: Wolters Kluwer Health.

Tracy, E. T. et al. (2010) "Protocolized approach to the management of congenital diaphragmatic hernia: benefits of reducing variability in care," Journal of Pediatric Surgery, 45(6), pp. 1343-1348. doi: 10.1016/j.jpedsurg.2010.02.104.

Treiber, L. A. and Jones, J. H. (2018) "After the medication error: Recent nursing graduates' reflections on adequacy of education," Journal of Nursing Education. doi: 10.3928/0148483420180420-04.

Varkey, P., Reller, M. K. and Resar, R. K. (2007) "Basics of quality improvement in health care," Mayo Clinic Proceedings, 82(6), pp. 735739. doi: $10.4065 / 82.6 .735$.
Vincent, C. (2008) "Is health care getting safer?," BMJ, 337(11), pp. 12051207.

Welsh Government (2016) "Prudent Healthcare Securing Health and Well-being for Future Generations," Prudent Healthcare in NHS Wales, p. 23. doi: $10.1007 / \mathrm{s} 11284-014-1143-4$.

Woolf, S. H. et al. (1999) "Potential benefits, limitations, and harms of clinical guidelines," BMJ, 318(20), pp. 527-530. doi: 10.1118/1.1997631.

World Health Organization (2010) World Health Organization Meeting Report on the development of guidelines for Community Based Rehabilitation (CBR) programmes (1 st and 2. Malta: World Health Organization Press.

World Health Organization (2020) Disability and Health: Keyfacts, World Health Organization. Available at: https://www.who.int/en/newsroom/fact-sheets/detail/disabilityand-health (Accessed: January 26, 2021).

Zhang, A. H. and Liu, X. H. (2011) "Clinical pathways: Effects on professional practice, patient outcomes, length of stay and hospital costs," International Journal of Evidence-Based Healthcare, 9(2), pp. 191-192. doi: 10.1111/j.1744-1609.2011.00223.x. 